\title{
Tide and wind control of megalopal supply to estuarine crab populations on the Portuguese west coast
}

\author{
Henrique Queiroga ${ }^{1, *}$, Maria João Almeida ${ }^{1}$, Teresa Alpuim ${ }^{2}$, Augusto A. V. Flores ${ }^{3}$, \\ Sara Francisco ${ }^{3}$, Ignácio Gonzàlez-Gordillo ${ }^{1}$, Ana Isabel Miranda ${ }^{4}$, Inês Silva ${ }^{3}$, José Paula ${ }^{3}$ \\ ${ }^{1}$ Departamento de Biologia, Universidade de Aveiro, Campus Universitário de Santiago, 3810-193 Aveiro, Portugal \\ ${ }^{2}$ Departamento de Estatística e Investigação Operacional, Faculdade de Ciências, Universidade de Lisboa, Campo Grande, \\ 1749-016 Lisboa, Portugal
}

${ }^{3}$ IMAR-Laboratório Marítimo da Guia, Faculdade de Ciências da Universidade de Lisboa, Estrada do Guincho, 2750-642 Cascais, Portugal

${ }^{4}$ Departamento de Ambiente e Ordenamento, Universidade de Aveiro, Campus Universitário de Santiago, 3810 -193 Aveiro, Portugal

\begin{abstract}
Physical processes that force transport of planktonic larvae of invertebrates are responsible for some of the spatial and temporal variability in recruitment. We investigated the influence of tide- and winddriven circulation on intra-year variability of megalopal supply to populations of the crab Carcinus maenas in 2 estuaries on the Portuguese west coast. Daily data on physical variables and on supply and settlement of megalopae were subjected to time series analysis and multiple regression techniques in order to identify periodicity in the variables as well as time lags between larval supply and physical variables. Relaxation of northerly winds, which favor upwelling, was associated with temperature increase and subtidal sea level rise at the coast, which are indicative of coastal convergence of the surface layer. Supply of megalopae to the estuaries, as measured with passive plankton nets, followed a fortnightly cycle with maximum larval supply at the time of maximum tidal amplitude. Supply was enhanced by southerly winds, with delays of 0 to $-2 \mathrm{~d}$. Settlement of megalopae on artificial settlement substrates deployed on the bottom was uncoupled to supply at both estuaries. Therefore, transport of $C$. maenas megalopae to the nearshore is accomplished by onshore advection following downwelling winds, and supply to the estuaries occurs by selective tidal stream transport. Involvement of internal waves and internal tidal bores cannot be be ruled out, but very particular periodicities of the generating mechanisms would have to be assumed to account for the observed time lags.
\end{abstract}

KEY WORDS: Larvae - Recruitment - Carcinus maenas Upwelling · Tides

Resale or republication not permitted without written consent of the publisher

\section{INTRODUCTION}

Tides and wind-driven circulation are 2 of the most important physical processes that account for the variability of supply of larvae to littoral and estuarine systems. The current paradigm holds that recruitment of estuarine species with a dispersive larval phase is a 2-step process (Boehlert \& Mundy 1988, Shanks 1995): (1) onshore transport of larvae over the shelf and (2) passage through inlets and upstream movement in search of a suitable habitat for settlement. These studies emphasize the role of active behaviour of larvae, principally the vertical position in the water column, in the control of horizontal transport. Because the environmental processes that dominate neritic and estuarine waters differ, different behavioural mechanisms must be activated during the 2 steps. The following discussion on potential transport processes concern crustacean larvae, but similar evidence regarding fish also exists (e.g. Boehlert \& Mundy 1988, Epifanio \& Garvine 2001, Sponaugle et al. 2005).

Tides are the driving force that cause internal waves. In thermally stratified waters, tidal currents flowing over the shelf break cause waves in the thermocline that are topographically trapped. At slack tide the waves are released and progress towards the coast. Shanks $(1983,1988)$ has proposed that internal waves can transport neustonic larvae across the shelf, at the convergence zone that is entrained by the internal waves. Since formation and propagation of internal waves is related to tidal amplitude (but not necessarily during spring tides; see Pineda 1994) this mechanism 
could result in pulses of supply of megalopae occurring at intervals of $2 \mathrm{wk}$. In linear internal waves, particles pass into and out of the convergence zone, and onshore transport does not occur (Franks 1997). However, in non-linear, strongly asymmetric internal waves, the speed of the surface current generated by the wave can be higher than the phase speed, resulting in an accumulation of particles at the front of the wave, and subsequent onshore transport (Pineda 1999, Helfrich \& Pineda 2003). This mechanism can only operate provided larvae are neustonic, such as in the case of several decapod megalopae (Zeldis \& Jillet 1982, Shanks 1985). Some estimates point to long-term mean onshore transport velocities of $0.005 \mathrm{~m} \mathrm{~s}^{-1}, 2$ orders of magnitude below the phase speed of the wave, suggesting that they may not be significant for crossshelf transport of larvae (Epifanio \& Garvine 2001).

As internal waves approach shallow waters they break in a similar way as surface waves do, causing internal tidal bores. Pineda $(1991,1994)$ proposed the hypothesis that shoreward-breaking internal waves produce nearshore upwelling and transport subsurface water to the shore, carrying with it water-column larvae residing below the thermocline. Internal bores may also produce onshore flow at the surface, following the downwelling and seaward flow of the denser water that was previously advected to the surface. In this case, neustonic larvae would be transported shoreward (Pineda 1994). Both mechanisms evoking the role of internal tidal bores would also result in pulses of larval supply occuring at intervals of $2 \mathrm{wk}$. However, internal bores do not necessarily occur around spring tides, as shown by Pineda (1991, 1995). Internal waves may have larger amplitude than surface waves, and therefore may break at considerable distances from the shore. The scale of the shoreward transport is not known, but it is likely that internal bores may control supply of larvae only in shallow nearshore waters (Pineda 1994).

Wind-driven circulation has been implied in the cross-shelf transport of barnacle and decapod larvae in eastern boundaries of the North Pacific and North Atlantic, which are dominated by upwelling (Roughgarden et al. 1991, Almeida \& Queiroga 2003). At these types of coasts, onshore transport of larvae takes place during the relaxation of the equatorward winds, which causes onshore convergence of the surface layer and collision of upwelling fronts with the coast. Differences in upwelling strength along the coast (Connolly et al. 2001), as well as alongshore flow resulting from intensification and relaxation of upwelling-favorable winds (Wing et al. 1995), may also result in temporal and spatial variation of larval supply and affect recruitment at regional and local scales. Episodic wind events with return periods of weeks to months that result in coastal increase of subtidal sea level (SSL) and storm surges (such as the passage of fronts and hurricanes), have been implied in augmented supplies of crab megalopae to estuarine systems (Goodrich et al. 1989). On a regional scale, the opposing effects of near-coast buoyancy flow provided by river discharge and wind-driven circulation further offshore may provide a mechanism for retention of larvae, as indicated by several studies on the western North Atlantic concerning fish and decapod larvae (Epifanio \& Garvine 2001). Down-thewind transport of barnacle larvae has also been implicated as the mechanism underlying the correlations between onshore wind intensity and settlement of barnacle cypris (Hawkins \& Hartnoll 1982).

Other physical mechanisms for cross-shelf transport of larvae have also been proposed (reviewed by Shanks 1995), such sea breezes (see Tapia et al. 2004), Langmuir circulation, and density-driven flow. However, the evidence supporting these mechanisms is considerably less extensive.

A clear conceptual background for upstream movement in estuaries and semi-enclosed bodies of water dominated by tidal circulation is emerging. Invertebrate and fish larvae migrate into estuaries using selective tidal stream transport (STST, reviewed by Forward \& Tankersley 2001). During upstream STST, larvae settle on, or move close to, the bottom during ebb tide, to avoid being displaced seaward, and they ascend in the water column during flood tide. The best description of the bio-physical control of STST is available from a series of field and laboratory studies on crab megalopae, which are consistently more abundant in estuaries during night flood tides than at other times (e.g. Little \& Epifanio 1991, Queiroga et al. 1994). This pattern arises from a combination of inhibition of swimming activity by high light intensities, ascent in the water column triggered by increases of hydrostatic pressure and salinity during flood, and sustained swimming in the presence of high turbulence levels. Chemical substances present in estuarine water, which result from the decomposition of organic matter, inhibit swimming during the day and cause sinking to the bottom (Forward \& Rittschof 1994, Forward et al. 1997). This behavior may enhance concentration of megalopae close to estuarine inlets. As the tide begins to rise, the concurrent increase of pressure and salinity above species-specific threshold levels triggers an ascent in the water column that promotes the transport of the megalopae into the estuary (DeVries et al. 1994, Tankersley et al. 1995). Swimming is maintained during the whole duration of the flood tide by high levels of turbulence, and during slack-after-high-water the megalopae stop swimming due to decreased turbulence levels and drop to the bottom, where they remain during the ensuing ebb tide, because the 
salinity drop overrides the effect of turbulence (Welch et al. 1999, Welch \& Forward 2001). In some cases endogenous rhythms synchronised with the tide also assist in upstream STST (DeVries et al. 1994). The threshold rates of increase in pressure and salinity necessary to elicit the swimming response during flood (Tankersley et al. 1995) may be the basis for the increased abundance during spring tides and for the clear 2 wk pattern detected in meso-tidal systems (Moser \& MacIntosh 2001, Paula et al. 2001), contrasting with the diffuse pattern detected in systems with a lower tidal range (e.g. van Montfrans et al. 1995). The larger the tidal range, the higher the pressure and salinity increase rates during flood, and the more likely crab megalopae respond by swimming from the bottom to the water column.

In the present study we investigated temporal and spatial patterns of invertebrate larval supply and settlement in estuaries on the Portuguese west coast. Our aim was to identify the main physical processes that control intra-year variability of recruitment in the portunid crab Carcinus maenas. The Portuguese coast has a semidiurnal tidal regime where the range of the tide averages $2 \mathrm{~m}$ and is subjected to seasonal upwelling (Wooster et al. 1976). C. maenas forms large populations in Portuguese estuaries and has a planktotrophic larval phase that develops in shelf waters, showing maxima of abundance in the middle shelf in northern Portugal (Queiroga 1996).

Our first hypothesis was that supply of megalopae should occur with a semilunar periodicity, because internal waves, internal tidal bores and STST are all related to tidal range. Our second hypothesis was that supply should increase following relaxation or inversion of upwelling-favorable equatorward winds, when coastal convergence of the surface layer takes place. We addressed these problems by obtaining daily series of abundance of megalopae in the plankton, settlement of megalopae on bottom-deployed collectors, and physical parameters related to tide amplitude and upwelling, during several months within the reproductive season, in 1 estuary in the northern (Ria de Aveiro) and 1 in the southern (Mira Estuary) part of the Portuguese west coast. In order to relate the change in abundance of megalopae inside the estuaries with shelf processes, observations of supply and settlement were conducted in the lower part of the estuaries, within 1 tidal excursion from the inlet.

\section{MATERIALS AND METHODS}

Oceanography of the Portuguese west coast. The Portuguese coast is located on the northern limit of the eastern North Atlantic upwelling region, where most of the climate and coastal hydrology is controlled by the position of the Azores anticyclone that migrates northward during spring (Fiúza et al. 1982, Haynes et al 1993). Two typical current patterns can be described in the shelf/slope system. (1) During winter, the Iberian Poleward Current, which normally flows over the slope, is reinforced by strong southwesterly winds associated with the passage of cold fronts, and the northward flow extends to the inner shelf (Frouin et al. 1990, Haynes \& Barton 1990, Haynes et al. 1993). Superimposed on the above regime, freshwater inflow from rivers (the Western Iberia Buoyant Plume) can force nearshore circulation in the neighborhood of estuaries. (2) In spring, a transition to equatorward flow occurs, typical of the upwelling regime driven by northerly alongshore winds. Northerly winds advect the surface layer offshore, causing a drop in sea level and a cooling of the surface water (Wooster et al. 1976, Fiúza 1984, Jorge da Silva 1992). The upwelling season typically lasts from April to September and has intensity maxima in July and August, although intense episodes can also happen during winter (Borges et al. 2003, Huthnance et al. 2002). Upwelling theory predicts that onshore convergence of the surface layer takes place as soon as equatorward winds relax (Bakun 1996); this does not require a complete reversal of the wind.

Larval biology of Carcinus maenas. The European common shore crab Carcinus maenas is a portunid species that forms large populations in Portuguese estuaries. In some cases, these estuaries sustain fisheries of local economic importance (Marques \& Costa 1983, Gomes 1991, Sprung 1994). This crab is one of the best studied invertebrate species and has an extensive geographical distribution, which has been exteded during the last century through artificial introduction to other continents followed by natural range expansion (Grosholz \& Ruiz 1995, d'Udekem d'Acoz 1999, Thresher et al. 2003). First zoeae hatch during nightly ebbs of neap tides and are quickly flushed into coastal waters (Queiroga et al. 1994, 1997). This process is controlled by an endogenous rhythm of vertical migration in synchrony with the tide, which maximizes downstream transport (Zeng \& Naylor 1996a, c, Duchêne \& Queiroga 2001). Larvae take 4 to $6 \mathrm{wk}$, depending on water temperature, to reach the megalopa stage in shelf waters (Dawirs 1985, Nagaraj 1993). Larvae of the species have been found throughout the top $60 \mathrm{~m}$ of water, with abundance maxima located on the middle shelf (Queiroga 1996). The megalopal stage appears to be neustonic only during the night (Zeng \& Naylor 1996b) and travels up the estuary during night flood tides using STST (Queiroga et al. 1994, Queiroga 1998, Zeng \& Naylor 1996b). Previous studies of megalopae supply to the Ria de Aveiro using plankton nets 
(Queiroga 2003) and artificial collectors (Almeida \& Queiroga 2003) detected a positive association with relaxation events of upwelling-favorable equatorward winds, but did not find any effect of tidal amplitude. The megalopae of $C$. maenas seem to settle in a variety of subtidal and intertidal estuarine habitats, showing a preference for those that are structurally complex (J. Paula unpubl.).

Sampling locations. The Ria de Aveiro is a shallow coastal lagoon on the northwest coast of Portugal with an average depth of $1 \mathrm{~m}$ (Fig. 1B,C). It can be considered a bar-built estuary according to the classification of Pritchard (1967). The inlet is artificially maintained by 2 long concrete and stone jetties approximately perpendicular to the coast line. The topography of the Ria de Aveiro is rather complex, with 4 main channels that radiate from the inlet and several branches, islands and mudflats forming an intricate system that provides a good habitat for Carcinus maenas. The River Vouga is the most important of the rivers and smaller streams that discharge into the lagoon, accounting for $2 / 3$ of the total freshwater input (Vicente 1985). Circulation in the lagoon is dominated by tides, except during periods of peak flow, which are coincident with heavy rainfall (Barrosa 1985, Dias 2001). Tides are semidiurnal with an average range of $2.1 \mathrm{~m}$, and ranges of ca. $1 \mathrm{~m}$ and $3 \mathrm{~m}$ in extreme neap and spring conditions. The Canal de Mira (not part of the Mira Estuary), where sampling took place, runs SSW from the inlet for $25 \mathrm{~km}$, parallel to the coast. This channel can be considered a small subestuary in itself. A headland that separates the inlet channel into 2 different arms diverts about $20 \%$ of the tidal prism of the flooding tide to the Canal de Mira. Other communications with the rest of the system are negligible. At the southern end, Canal de Mira receives a continuous freshwater supply from a small system of ponds and streams. In the area of the sampling stations the tides are slightly asymmetrical, with flood duration exceeding ebb duration by $25 \mathrm{~min}$ on average. The delay of the tide at the sampling sites relative to the inlet varies between 20 and 40 min, according to tidal amplitude and phase (Queiroga 1995). Salt marshes occur throughout the lower

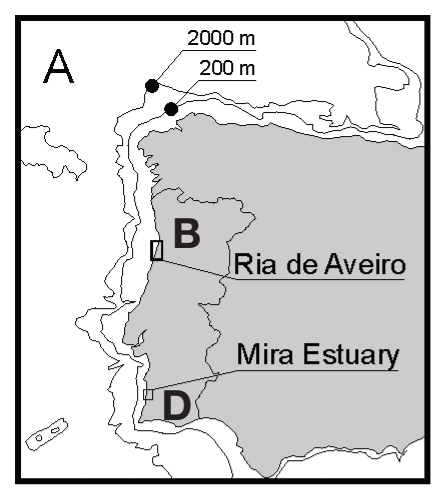

Fig. 1. Sampling locations. (A) Iberian Peninsula; $(B, C)$ Ria de Aveiro; (D,E) Mira Estuary. (C) and (E) show sampling sites. Arrows in (B) and (D): weather stations. Triangle in (D): hydrological buoy at Sines
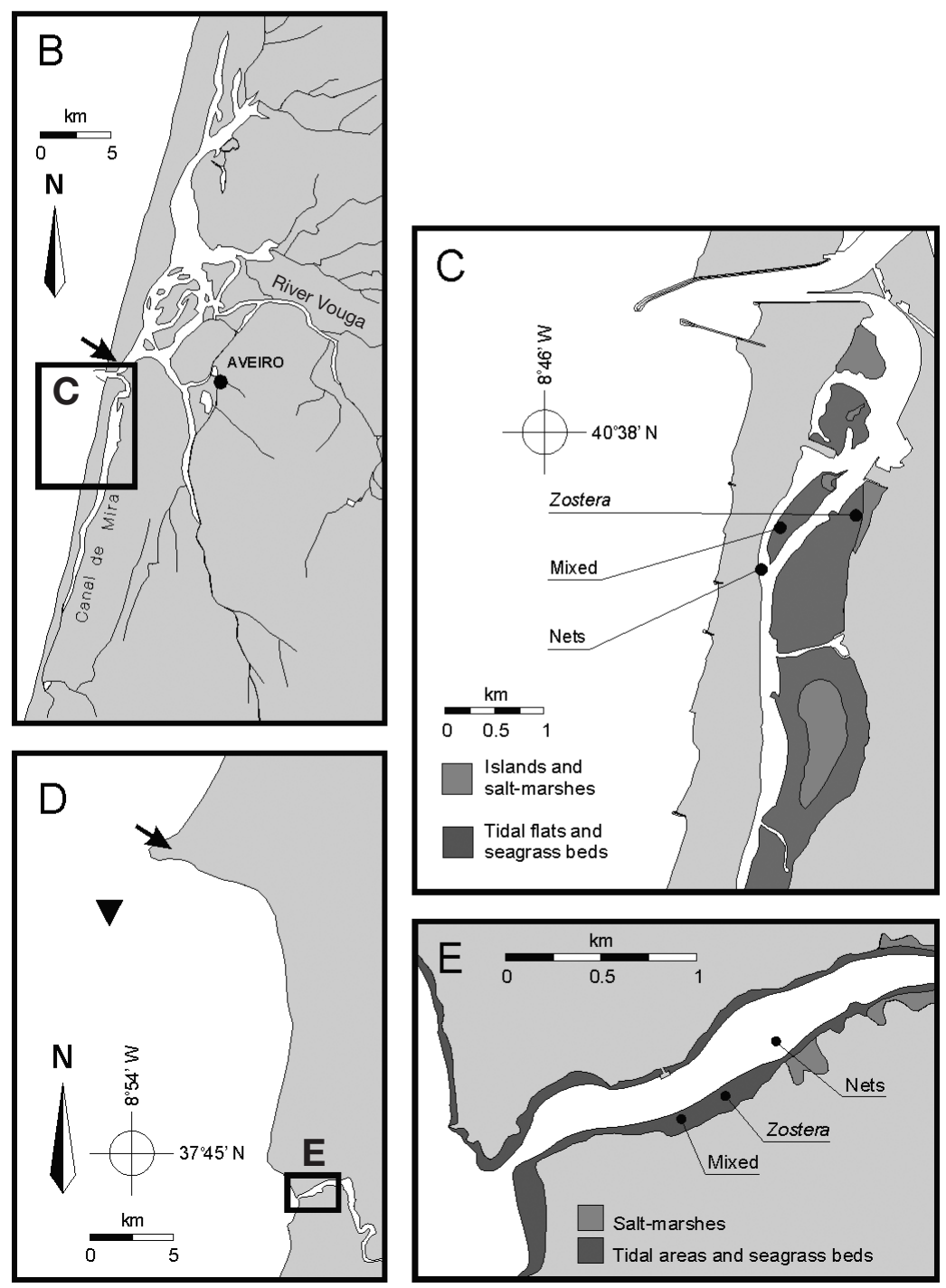

$10 \mathrm{~km}$ of the Canal de Mira, and intertidal areas with dense cover of seagrass meadows formed by Zostera noltii are common.

The Mira Estuary (as distinct from the Canal de Mira) is a morphologically simple estuary located on the southwestern Portuguese coast (Fig. 1D,E). The 
estuarine section extends about $40 \mathrm{~km}$ inland in a single channel. In the lower $2 \mathrm{~km}$ the estuary presents a flood delta composed of 2 main complexes of sandy shoals that emerge during spring low water. Maximum depth is around $20 \mathrm{~m}$ at the Vila Nova de Milfontes bridge ( $2 \mathrm{~km}$ from the mouth), and upstream the single channel is about 8 to $10 \mathrm{~m}$ deep, becoming shallower inland. The tide is semidiurnal with ranges of ca. $1.0 \mathrm{~m}$ at neap tide and $3.2 \mathrm{~m}$ at spring tide. Runoff is largely controlled by the Santa Clara dam located $60 \mathrm{~km}$ upstream. The Mira River has a limited and strongly seasonal freshwater flow, and since the dam was built it tends to accumulate sediments of marine origin in the lower reaches. The estuary waters are mixed during spring tides, with turbulence homogenizing the water column, and during neap tides stratification occurs (Andrade et al. 1991, Blanton et al. 2000). Fringing salt marshes occur as far as $20 \mathrm{~km}$ upstream. In the lower $8 \mathrm{~km}$ extensive seagrass meadows occur, subtidally Zostera marina and intertidally Z. noltii. The delay of the tide at the sampling sites relative to the inlet is similar to that observed in the Canal de Mira, Ria de Aveiro (Andrade et al. 1991).

Field sampling. The basic sampling strategy consisted of the acquisition of daily data on supply of megalopae, settlement of megalopae, wind stress, tidal range, SSL and sea surface temperature (SST) for periods of several months during the reproductive season of Carcinus maenas, at both locations. The sampling period lasted from 1 April to 25 July 2002 at the Ria de Aveiro and from 22 March to 6 July 2002 at the Mira Estuary, although not all data series within each location had the same length.

Supply of megalopae was measured with the use of passive plankton nets, which were specifically designed for sampling only during the flood tide. The nets had a length of $2 \mathrm{~m}$, a rectangular opening of $0.40 \times 0.25 \mathrm{~m}$ and a $500 \mu \mathrm{m}$ mesh. Inside the net a funnel of $0.40 \mathrm{~m}$ length was attached to the opening frame. This funnel was also made of $500 \mu \mathrm{m}$ mesh and had a circular posterior opening $0.17 \mathrm{~m}$ in diameter. Two of these nets were used at 1 site at each location (Fig. 1C,D), one floating just beneath the surface and the other placed above the bottom. Both nets were attached to light stainless steel frames that could be placed above the bottom, suspended from a floating pier or made to float with the use of small buoys. Whether deployed over the bottom or near the surface, the opening of the nets always faced the inlet of the estuary. This was accomplished by securing the frames upstream and downstream with anchors, which were attached to the anterior and posterior ends of the frames, respectively. The attachment of the nets to the frames was done so that the nets would freely filter the water during flood. During ebb both the interior funnel and the exterior net wall collapse, preventing the collected material from escaping. The nets were deployed during diurnal low water and remained in place for about $25 \mathrm{~h}$ until the next diurnal low water, when the contents were recovered. When low water occurred close to sunset, the nets were removed during the morning low tide of the second day, having been deployed for $37.5 \mathrm{~h}$. The ability of the net design to prevent the loss during ebb of the plankton collected during flood was tested in an experiment at the Ria de Aveiro between 25 October and 23 November 2001. During this period, 5 sampling assays were conducted, each lasting for $25 \mathrm{~h}$ and starting at low water. In each assay 2 nets were set beneath the surface, parallel to each other, with one of the nets continually immersed for $25 \mathrm{~h}$ periods, while the other was immersed only during the 2 floods within each $25 \mathrm{~h}$ period. The plankton was separated into several taxonomic groups and counted (Table 1). A paired-sample Student's $t$-test (Sokal \& Rohlf 1995) was applied to each taxonomic group. The difference between the nets was not significant for all taxa ( $p>0.05)$, indicating that the net that fished continuously for $25 \mathrm{~h}$ periods retained the material collected during flood. In fact, the net that was continually immersed collected $15 \%$ more individuals than the other net. All analyses were conducted on number of megalopae collected daily by the nets, without correcting by filtered volume. The main reason for doing this is that during a large extent of the neap tides the speed of tidal currents is below the working range of most flowmeters. Therefore, attempts to standardise megalopae numbers by volume would be subject to a large error. Standardisation by volume would hardly affect the results, because differences in supply ranged from 0 (or almost 0 ) ind. $\mathrm{d}^{-1}$ during neap tides, to several tens

Table 1. Average number of individuals $( \pm 1 \mathrm{SE}$ ) of several taxa collected by 2 passive plankton nets deployed for periods of $25 \mathrm{~h}$ and 2 consecutive floods. $t$-tests performed for paired samples

\begin{tabular}{|lcccrc|}
\hline Taxon & Continuous & Flood only & df & $t$ & $\mathrm{p}$ \\
\hline Copepods & $62.6 \pm 12.6$ & $58.2 \pm 9.1$ & 4 & 0.405 & $>0.50$ \\
Isopods & $129.4 \pm 64.7$ & $76.2 \pm 8.5$ & 4 & 1.769 & $>0.10$ \\
Amphipods & $209.8 \pm 50.1$ & $258.6 \pm 21.6$ & 4 & -2.532 & $>0.05$ \\
Mysids & $630.6 \pm 227.4$ & $963.8 \pm 28.5$ & 4 & -1.115 & $>0.25$ \\
Decapod larvae & $306.6 \pm 131.5$ & $254.4 \pm 16.3$ & 4 & 0.344 & $>0.50$ \\
Appendicularians & $104.2 \pm 29.8$ & $15.4 \pm 4.4$ & 4 & 2.738 & $>0.05$ \\
Chaetognaths & $36.6 \pm 24.9$ & $54.6 \pm 5.3$ & 4 & -0.753 & $>0.25$ \\
Fish larvae & $20.8 \pm 9.0$ & $15.2 \pm 3.9$ & 4 & 0.857 & $>0.25$ \\
Total & $1500.6 \pm 346.8$ & $1696.4 \pm 45.3$ & 4 & -0.464 & $>0.50$ \\
\hline
\end{tabular}


(Ria de Aveiro) or hundreds (Mira Estuary) ind. $\mathrm{d}^{-1}$ during spring tides, while differences in tidal currents between neap and spring tides are on the order of 1:2 at most. Moreover, standardisation would not affect the phasing of the supply peaks relative to tidal range, because they occurred around maximum amplitude tides.

Megalopae settlement was measured with the use of artificial collectors made with 'hoghair' filter material. Artificial collectors of this kind have been extensively used in studies of crab megalopae recruitment in coastal systems (e.g. Metcalf et al. 1995, van Montfrans et al. 1995, Paula et al. 2001). In the present case the collectors were not of the floating type as originally developed (Metcalf et al. 1995), but rather deployed over the bottom of intertidal flats. This methodology was used successfully at the Ria de Aveiro for the description of recruitment patterns of Carcinus maenas (Almeida \& Queiroga 2003) and allows the separation of supply (as recorded from the density in the plankton measured with the plankton nets) from settlement. Two sampling sites were selected at each location: 1 area with soft mud densely covered with the eelgrass Zostera noltii, and a mixed area (Fig. 1C,E). The mixed area at the Ria de Aveiro was characterised by a muddy sand sediment with shells and sparse cover of Enteremorpha sp. and Gracilaria sp. At the Mira Estuary the mixed area also had muddy sand sediment, but with the presence of scattered boulders and a sparse cover of $Z$. noltii. In the Ria de Aveiro, 5 collectors with dimensions of $0.50 \times 0.40 \mathrm{~m}$ were randomly deployed every day at each site, lying at distances of 2 to $4 \mathrm{~m}$ from each other, during the diurnal low tide, and fixed to the bottom with wire stakes. For logistic reasons one of the sampling sites of the Mira Estuary had to be discontinued $67 \mathrm{~d}$ after the start of the experiment. Since numbers of megalopae collected at the $Z$. noltii site were much lower than at the mixed site, sampling proceeded at the mixed site. Moreover, only 4 replicates were used daily at each site in the Mira Estuary. Similarly to the plankton nets, the collectors were also deployed during the diurnal low water. In the next diurnal low tide they were removed, replaced by new collectors and taken to the laboratory in plastic bags. Crab megalopae and juveniles were recovered by immersing the collectors in fresh water, rinsing them with freshwater jets through a $0.5 \mathrm{~mm}$ sieve and sorting out the animals from the debris.

Hourly measurements of wind intensity and direction were obtained from a meteorological mast installed at S. Jacinto, in the case of the Ria de Aveiro, and from the Sines harbor weather station, for the Mira Estuary (Fig. 1B,D). The mast at S. Jacinto was situated $2.5 \mathrm{~km}$ to the northeast of the Ria de Aveiro inlet, on the sand bar that separates the northern part of the estuary from the sea. Sines harbor lies $22 \mathrm{~km} \mathrm{NNW}$ of the Mira Estuary. The wind data were treated as follows. First, the hourly wind stress was calculated, for both east-west $\left(T_{u}\right)$ and north-south $\left(T_{V}\right)$ components, through the equation (Jorge da Silva 1992):

$$
\left(T_{u}, T_{v}\right)=-\rho_{\mathrm{a}} C|\vec{v}|(u, v)
$$

where $\rho_{\mathrm{a}}$ is air density $\left(1.12 \mathrm{~kg} \mathrm{~m}^{-3}\right), C$ is a constant drag coefficient $(0.012), \vec{V}$ is wind-velocity vector, $u$ is the east-west component of the wind (positive indicates easterly wind) and $V$ is the north-south component (positive indicates northerly wind). Since the Portuguese west coast has an approximate north-south orientation, $T_{u}$ and $T_{V}$ correspond to cross-shore and alongshore stresses, respectively. Then the average daily wind stress for each component of the wind was computed.

Sea level data were obtained from the Aveiro and Sines harbor tide gauges, which are located at the inlet channel of the Ria de Aveiro, and on a hydrological buoy $5 \mathrm{~km}$ from Sines, respectively. Daily tidal range was computed as the difference between the average of the 2 daily maximum heights and the average of the 2 daily minimum heights. Daily SSL was calculated by running a $13 \mathrm{~h}$ moving average over the hourly sea level values in order to remove the tidal signal, followed by the calculation of the average of the filtered values for each day. Daily SST recorded at Leixões, $60 \mathrm{~km}$ north of the Ria de Aveiro, by the weather station of the Portuguese Instituto de Meteorologia, and by the hydrological buoy off Sines, were used in the study. The SST anomaly was calculated as the difference between the temperature at the coast and the temperature at an Azores station. SST anomaly at the coast relative to an offshore station not affected by upwelling has been used as an upwelling index.

For simplification, all references to wind and hydrological variables will be made as Ria de Aveiro or Mira Estuary.

Statistical analysis. In order to identify the nature of the mechanisms that control supply of Carcinus maena megalopae it is necessary to identify the delay between tidal or wind forcing and the subsequent response of the coastal ocean and of larval supply. This was done using cross-correlation and least squares regression applied to series where wind or tidal range preceded hydrographical variables and supply, at lags $\leq 5 \mathrm{~d}$ (it is not possible to interpret meaningfully situations in which wind or tides precede the response of hydrographic variables or supply of larvae by $>5 \mathrm{~d}$ ). These lags are indicated throughout this paper by negative numbers. Spectral analysis and autocorrelation were used to identify the periodicity of the time series and the dependence of the data. 
Upwelling theory predicts that an increase of the equatorward wind stress will cause a drop of the SSL and a decrease in SST at the coast. In order to investigate these effects and to determine whether the upwelling mechanism was operating during the study period, cross-correlations (Chatfield 1996) between the alongshore component of wind stress and SSL, SST, and SST anomaly were computed for time lags of 0 to $-5 \mathrm{~d}$. All data series were moderately to strongly autocorrelated at a lag of $-1 \mathrm{~d}$, as indicated by their partial autocorrelation function. This autocorrelation could inflate the cross-correlation values. In order to remove the autocorrelation all series were differenced before calculating the cross-correlations, using a time lag of 1 d. Spectral analyses (Chatfield 1996) were also applied to the alongshore wind stress, in order to detect any periodicity of the wind, using the Kolmogorov-Smirnov $d$ statistic to assess significance.

Cross-correlations were used to investigate the relationship between tidal range and abundance of megalopae in the nets and on the collectors, as well as to compare captures of megalopae in the nets and on the collectors, within and across locations. Again, because of dependence of the data at a $-1 \mathrm{~d}$ lag, crosscorrelations were computed over the differenced series. Student's $t$-test was used to assess differences in the intensity of settlement on the collectors between the mixed and Zostera noltii sampling sites (Sokal \& Rohlf 1995). Estimates of precision of the mean are reported as SE throughout the text.

Visual inspection of the data on abundance of megalopae in the nets indicated a very clear periodicity related to the tide amplitude cycle (see Figs. 5A \& 6A). This was confirmed by spectral and cross-correlation analysis. Spectral analysis applied to the series of abundance of megalopae showed peaks in the periodograms at 14.6 and $14.0 \mathrm{~d}$, and cross-correlation analysis indicated that correlation between abundance in the plankton nets and tidal range was highest at time lags of 0 and of -14 to $-15 \mathrm{~d}$ for both locations. These observations suggested that tide amplitude was the primary factor controlling supply of megalopae to the estuaries. Therefore, in order to investigate the effect of wind on supply of megalopae the effect of tide amplitude had to be taken into account. This was accomplished by fitting a least squares regression model to the data on supply of megalopae, using, as the independent variables, wind and a set of sine and cosine functions accounting for the semilunar cycle of tidal range. Descriptions of the use of regression methods for the analysis of biological rhythms, which are usually referred to as periodic regression, can be found in Batschelet (1979) and deBruyn \& Meeuwig (2001). In our case we used the property that any periodic function with a period equal to an entire number can be described by a linear combination of sine and cosine functions with periods equal to submultiples of the period of the main cycle (Wei 1990), and adjusted the model:

$$
M e g_{d}=a_{0}+\sum_{i=1}^{7} a_{i} \cos \left(\frac{2 \pi i d}{14}\right)+\sum_{i=1}^{6} b_{i} \sin \left(\frac{2 \pi i d}{14}\right)+c_{1} \tau_{d}+e_{d}
$$

where $\mathrm{Meg}_{d}$ is the average daily abundance of megalopae in the 2 plankton nets (i.e. supply); $d$ is the day of the year; $\tau_{d}$ is the average daily alongshore wind stress; $a_{0}$ to $a_{7}, b_{1}$ to $b_{6}$ and $c_{1}$ are regression coefficients; $e_{d}$ is the random error term and $i$ is an integer dummy variable that generates the periodic components ( $i$ runs from 1 to 7 in the case of cosine functions, and from 1 to 6 in the case of sine functions, since the sine of multiples of $\pi$ is null). We chose $14 \mathrm{~d}$ as the approximation of the period of the semilunar cycle instead of the more commonly used value of $15 \mathrm{~d}$, because the spectral analysis had shown strong components at periods of 14 and $14.6 \mathrm{~d}$ in the supply data. Variables that were not significant were removed, stepwise, from the analysis and a reduced model was fitted with the remaining variables.

We decided to use regression instead of ARIMA (auto-regressive integrated moving average) and Transfer Function models (Chatfield 1996, Brockwell \& Davis 2002), because linear regression is a robust and flexible tool for discovering and modeling relationships among variables, which is our main goal in this work. It provides estimators for the coefficients that are optimal, as well as good estimates for their SDs, allowing accurate statistical tests on the significance of the variables in study. Furthermore, the coefficients and terms in the regression model have a clear biological and physical meaning, which is not the case in ARIMA. Only the alongshore wind stress was used in the analysis because of upwelling theory and because crossshore wind stress was always positive during the period of study (except for Days 78 to 90 at Mira Estuary) and showed small amplitude fluctuations (see Figs. 2A \& 3A). The wind stress effect on circulation of the coastal ocean and settlement may occur with a delay of several days. In addition, this effect may not depend uniquely on the wind that was blowing in a particular day, but on the cumulative effect of wind events over several days. In order to test the effect of wind episodes spanning $>1 \mathrm{~d}$, cumulative wind stress vectors were constructed by summing wind stresses over time windows of 2,3 and 4 consecutive days, backwards from each day, for each of the 2 locations. Cumulative wind stress vectors for $>4 \mathrm{~d}$ were not calculated, because previous studies (Fiúza 1984), and the spectral analysis of the wind time series reported in the present study (see Fig. 4), indicated strong periodicities of 6 to $9 \mathrm{~d}$. Separate models were applied using lags of 0 to $-5 \mathrm{~d}$, in order to test for delayed effects of wind. 
At both locations, for all combinations of wind stress vectors and lags between wind stress and supply, the residuals produced by the adjustment of the regression models presented an autocorrelation structure that followed a first order autoregressive process. This may result in incorrect significance values being assigned to the statistical tests (see Fuller 1976). However, under these circumstances, the least squares estimators of the coefficients keep their optimality properties, although their variances have to be recalculated taking into account the correlation structure of the residuals. For a first order autoregressive process this may be done applying the transformation $x_{d}-\phi x_{d-1}$ to all the independent variates $x$, where $\phi$ represents the estimated autoregressive coefficient. Then, the usual formula for the variance/covariance matrix of the least squares estimators can be used, where the variance of the residuals is replaced by the variance of the white noise sequence associated with the autoregressive error term (Alpuim \& El-Shaarawi in press).

Because the overall level of supply, wind stress, and tidal range did not appear to consistently increase or decrease with time, trends were not removed. Supply of crab larvae to coastal habitats seems to be inherently 'spiky' (e.g. van Montfrans et al. 1995, Paula et al. 2001), with a few days with very high values interspersed with several days with zero or very low values. Moreover, visual inspection of the supply series did not detect higher variances associated with higher supply, indicating the absence of multiplicative effects (Chatfield 1996). Therefore, we decided not to take logarithms of the data in order to preserve their natural variability. A sensitivity test of the regression model (not shown) indicated a poorer fit to the log-transformed observations and a lower significance of the coefficients, but the time lags with the highest significant fits were the same.

\section{RESULTS}

NNW winds dominated during the study period at both locations, as evidenced by wind stresses with a negative alongshore component and a positive cross-shore component of lesser magnitude on most of the days (Figs. 2A \& 3A), but events of weak to moderate southwesterly winds were also observed. The most important wind events occurred from Days 70 to 77 at Mira Estuary, prior to the beginning of biological sampling, when peak alongshore wind stress reached $0.15 \mathrm{~Pa}$, and from Days 131 to 137 and 140 to 144 at Ria de Aveiro, with peak values of $0.04 \mathrm{~Pa}$. The 2 last wind events were of shorter duration and reached lower stress values at Mira Estuary. Wind stress values during northerly winds were considerable higher at Mira Estuary (maximum value of $-0.15 \mathrm{~Pa}$ ) than at Ria de Aveiro (maximum value of $-0.06 \mathrm{~Pa}$ ). This may be related to the fact that the velocity sensor at Mira Estuary was located at a height of $50 \mathrm{~m}$ above ground, while the sensor at Ria de Aveiro was at $10 \mathrm{~m}$. Results of the spectral analysis of the alongshore component of wind stress revealed several spectral density peaks at periods of 2 to $9 \mathrm{~d}$ at both locations (Fig. 4, Ria de Aveiro: Kolmogorov-Smirnov $d=0.1980, \mathrm{n}=102$, $\mathrm{p}<0.01$; Mira Estuary: Kolmogorov-Smirnov $d=$ 0.2092, $\mathrm{n}=126, \mathrm{p}<0.001$ ). At Ria de Aveiro, 2 major peaks were detected at periods of 3.3 and $6.1 \mathrm{~d}$, while 4 lesser peaks at Mira Estuary were detected at periods of 2.5, 3.6, 4.5 and $8.7 \mathrm{~d}$. Significant cross-correlation values of alongshore wind stress with SSL, SST, and SST anomaly were always positive at both locations, indicating that an increase in northerly winds caused a decrease of SSL and SST at the coast (Table 2). However, the magnitude and timing of the response of the coastal ocean to the wind events differed between the 2 locations. At the Ria de Aveiro, a larger and quicker response was observed, with highly significant $(\mathrm{p}<$ 0.001) values for SSL at a $0 \mathrm{~d}$ lag, and for SST and SST anomaly at a lag of $-1 \mathrm{~d}$. At the Mira Estuary, SSL and SST anomaly were not associated with wind stress at any lag, but a significant ( $p<0.05)$ association with SST was observed at a lag of $-5 \mathrm{~d}$.

$$
\text { 造 }
$$
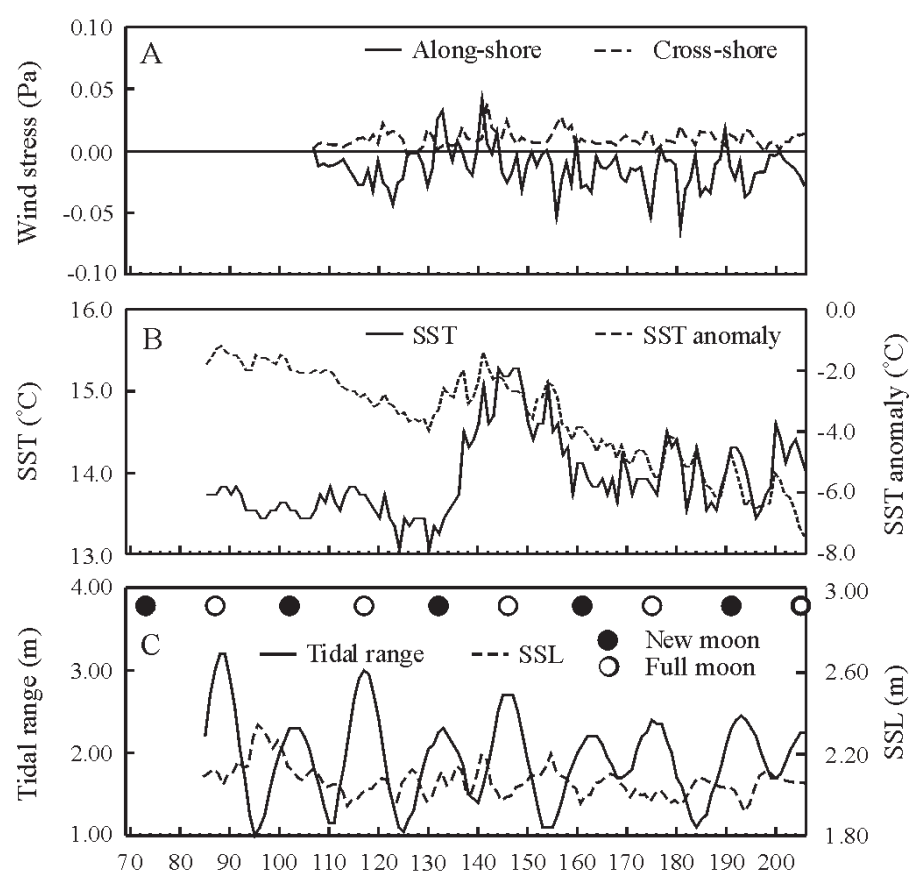

Day of the year

Fig. 2. Ria de Aveiro. Average daily values of (A) wind stress, (B) sea surface temperature (SST) and SST anomaly and (C) tidal range and subtidal sea level (SSL) 
Average daily captures of Carcinus maenas megalopae in the nets and on the collectors were much higher in the Mira Estuary than in the Ria de Aveiro (Table 3), being 18, 45 and 31 times higher in the nets and at the mixed and Zostera noltii sites, respectively. Supply of $C$. maenas megalopae to the estuaries, as measured by the number of megalopae collected daily by the passive nets, was clearly more intense around the full and new moons at both locations (Figs. 5A \& 6A). Spectral analysis of the supply series showed peaks in the periodogram at 14 and $14.6 \mathrm{~d}$ at the Ria de Aveiro and the Mira Estuary (Ria de Aveiro: Kolmogorov-Smirnov $d=0.5700, \mathrm{n}=102$, $\mathrm{p}<0.001$; Mira Estuary: Kolmogorov-Smirnov $d=$ $0.3639, \mathrm{n}=56, \mathrm{p}<0.001$ ), and cross-correlograms between tidal range and number of megalopae in the nets showed positive peaks at lags around 0 and $-15 \mathrm{~d}$ at the 2 sites (Fig. 7A,C), although values at the Mira Estuary were not significant at the $5 \%$ level. Captures of megalopae by the passive nets also differed across locations in that the surface and bottom nets collected similar numbers at the Ria de Aveiro (surface $7.8 \pm 1.2$, bottom $7.9 \pm 1.1$ ), whereas at the Mira Estuary the surface net collected more megalopae (surface $267 \pm 65$, bottom $19 \pm 4$ ). This is reflected in the larger SEs obtained at the Mira Estuary.

Table 4 reports the results of the application of the periodic regression models of supply of Carcinus maenas megalopae on a set of sine and cosine functions

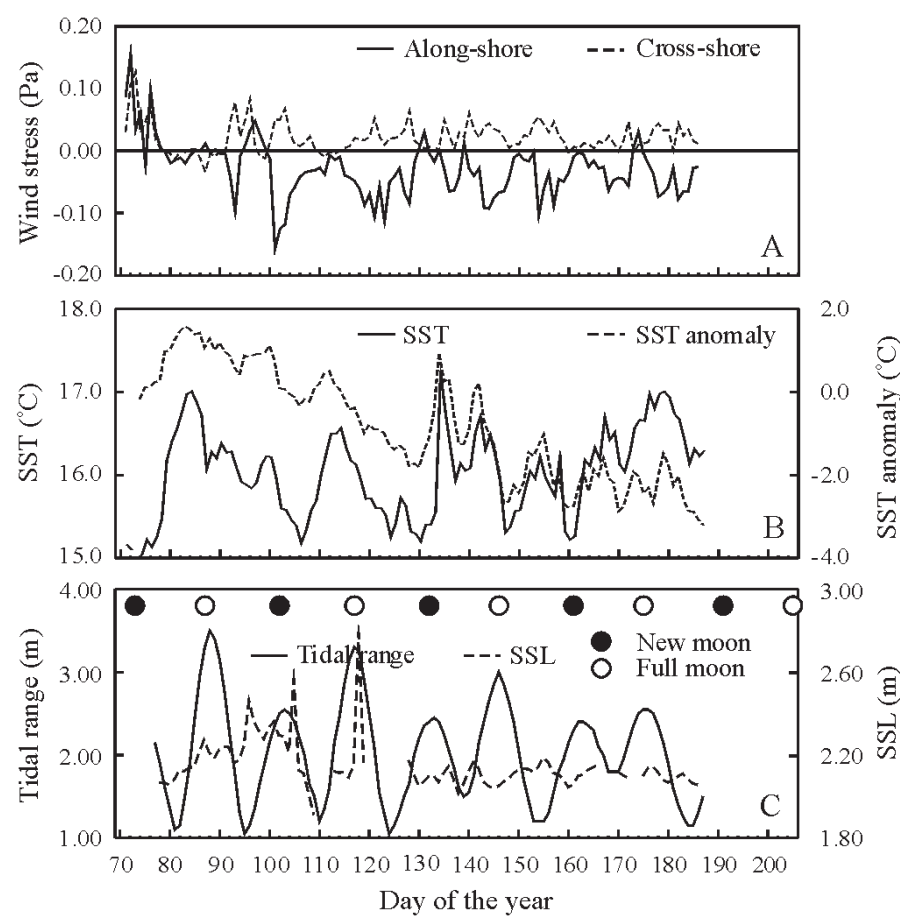

Fig. 3. Mira Estuary. Average daily values of (A) wind stress, (B) sea surface temperature (SST) and SST anomaly and (C) tidal range and subtidal sea level (SSL)

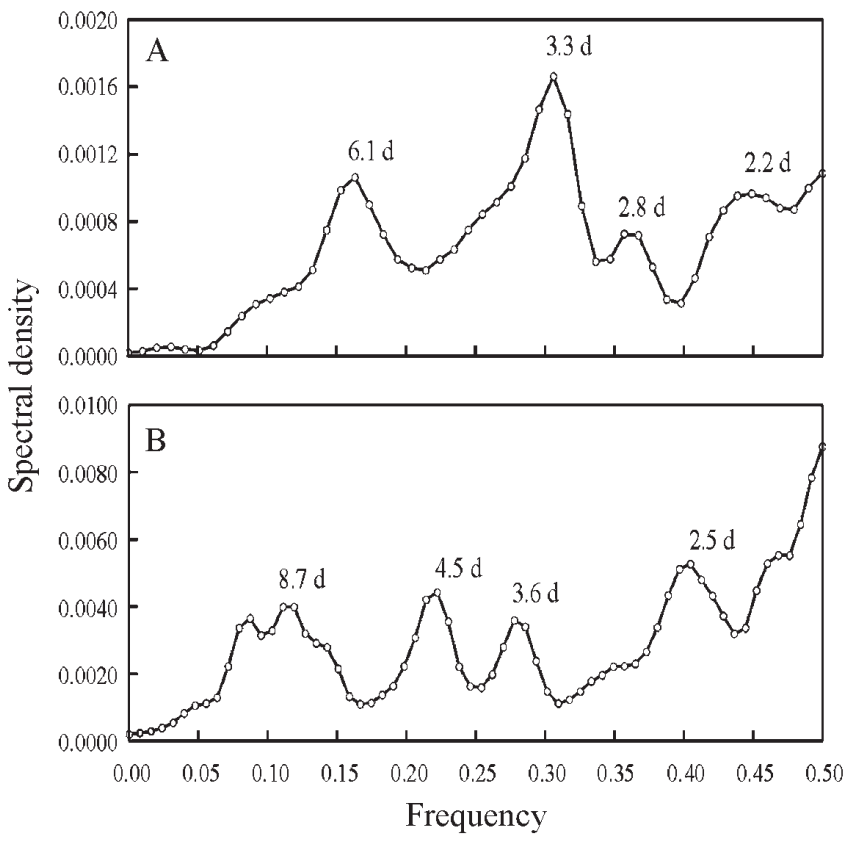

Fig. 4. Spectral analysis of alongshore component of wind stress measured at (A) S. Jacinto, Ria de Aveiro, and (B) Sines, Mira Estuary. Numbers above peaks represent the period of oscillation

describing the semilunar cycle and on wind stress, for those cases where wind stress was significant. In all cases the sine and cosine variable with a period of $14 \mathrm{~d}$ was significant, indicating a basic semilunar periodicity in the series of larval supply. In the case of the Ria

Table 2. Cross-correlation analysis between alongshore component of wind stress and subtidal sea level (SSL), sea surface temperature (SST), and SST anomaly, for Ria de Aveiro and Mira Estuary. Only significant correlations are reported. ${ }^{*} \mathrm{p}<0.05 ;{ }^{* * *} \mathrm{p}<0.001$

\begin{tabular}{|lrccc|}
\hline Location & Lag (d) & SSL & SST & SST anomaly \\
\hline Ria de Aveiro & 0 & $0.4805^{* * *}$ & - & $0.2087^{* *}$ \\
& -1 & - & $0.3467^{* * *}$ & $0.3775^{* * *}$ \\
Mira Estuary & -5 & - & $0.2871^{*}$ & - \\
\hline
\end{tabular}

Table 3. Carcinus maenas. Mean daily capture of megalopae in nets (ind. net ${ }^{-1} \mathrm{~d}^{-1}$ ) and on collectors (ind. collector ${ }^{-1} \mathrm{~d}^{-1}$ ) at the mixed and Zostera noltii sites, for Ria de Aveiro and Mira Estuary; n: no. of observations

\begin{tabular}{|llrrr|}
\hline Location & Site & \multicolumn{1}{c}{$\mathrm{n}$} & Mean & \multicolumn{1}{c}{$\mathrm{SE}$} \\
\hline Ria de Aveiro & Nets & 102 & 7.86 & 1.07 \\
& Mixed & 115 & 0.35 & 0.07 \\
& Zostera & 115 & 0.07 & 0.02 \\
Mira Estuary & Nets & 57 & 142.32 & 32.00 \\
& Mixed & 110 & 15.90 & 3.45 \\
& Zostera & 64 & 2.34 & 0.51 \\
\hline
\end{tabular}



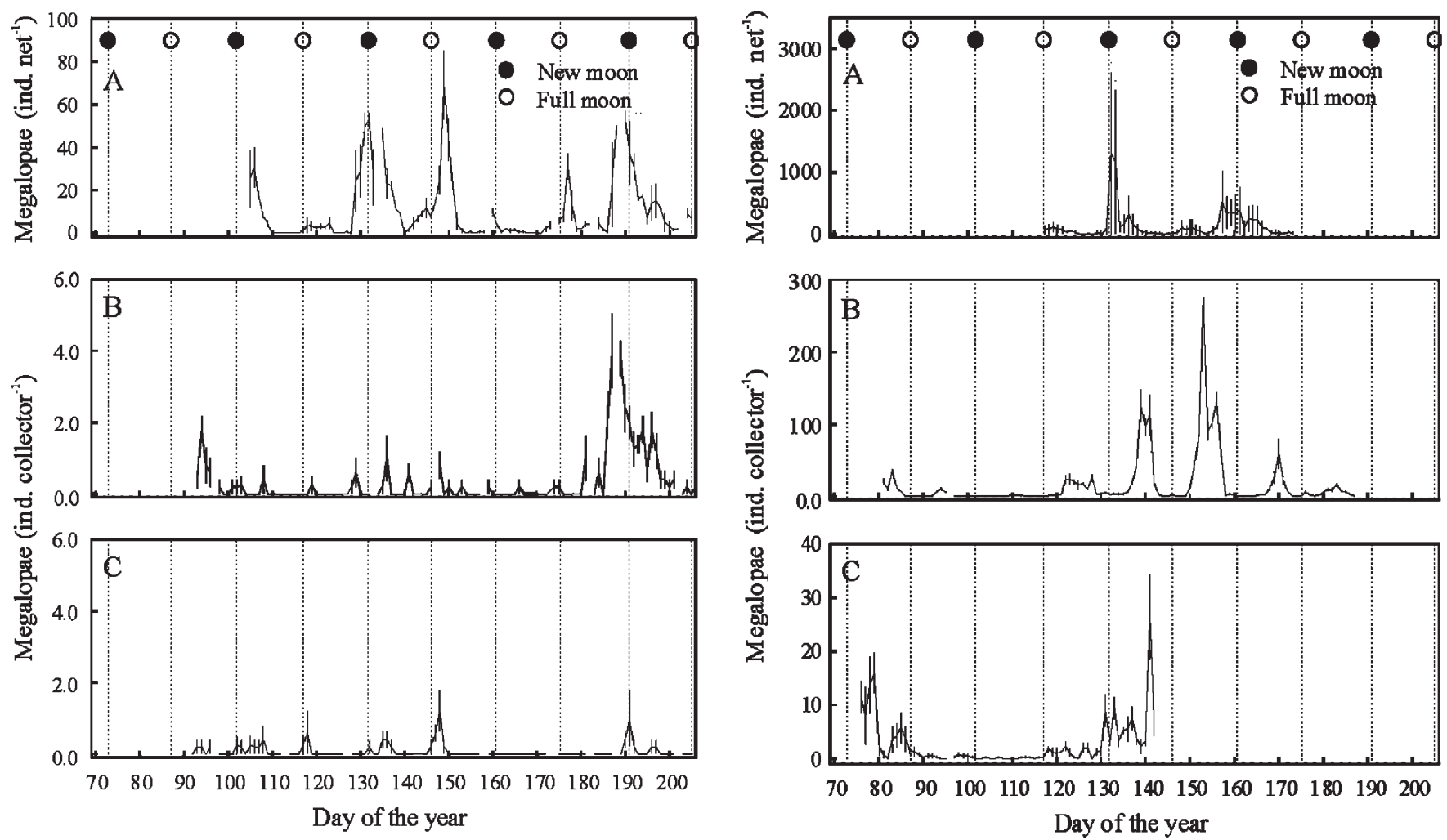

Fig. 5. Carcinus maenas. Average daily number of megalopae collected by (A) passive nets, and collectors at (B) the mixed and (C) Zostera noltii sites, in Ria de Aveiro. Error bars: \pm SE

Fig. 6. Carcinus maenas. Average daily number of megalopae collected by (A) passive nets, and collectors at (B) the mixed and (C) Zostera noltii sites, in Mira Estuary. Error bars: \pm SE

de Aveiro the cosine variable with a period of $2.8 \mathrm{~d}$ was also significant in 1 case, indicating the presence of a cyclic component with a higher frequency. Because of the existence of a correlation structure in the residuals (reflecting the influence of megalopae supply of any one day on that of the next day) the usual way of measuring the fit of the model through the $r^{2}$ statistic is not

appropriate in this case. Instead, we used a modification of this statistic, $r^{* 2}$, where the sum of squares of residuals was replaced by the sum of squares of the white noise sequence produced by the adjustment of an autoregressive process to the residuals. In this case, this sum of squares is a more realistic measure of the variability due to unexplained error. Overall fits, as

Table 4. Results of periodic regression models of megalopae supply to Ria de Aveiro and Mira Estuary on alongshore wind stress and on sine and cosine functions describing the semilunar cycle of tidal range, for those cases where wind stress was significant. Window: time window over which accumulated wind stress values were calculated. Values in parentheses: period of sine and cosine functions. Only independent variables used in the reduced models are reported (see 'Results' for further explanation). p: Significance of regression coefficients ( $\mathrm{p}<$ specified value) $r^{* 2}$ : modified coefficient of determination

\begin{tabular}{|c|c|c|c|c|c|c|c|c|c|c|c|c|}
\hline \multirow{2}{*}{$\begin{array}{l}\text { Lag } \\
\text { (d) }\end{array}$} & \multirow{2}{*}{$\begin{array}{l}\text { Window } \\
\text { (d) }\end{array}$} & \multirow{2}{*}{ Intercept } & \multicolumn{4}{|c|}{ - Regression coefficients } & \multirow[b]{2}{*}{ Intercept } & \multirow[b]{2}{*}{ Wind } & \multirow{2}{*}{$\frac{\mathrm{p}}{\operatorname{Cos}(14.00)}$} & \multirow[b]{2}{*}{$\operatorname{Sin}(14.00)$} & \multirow[b]{2}{*}{$\operatorname{Cos}(2.80)$} & \multirow[b]{2}{*}{$r^{* 2}$} \\
\hline & & & Wind & $\operatorname{Cos}(14.00)$ & $\operatorname{Sin}(14.00)$ & $\operatorname{Cos}(2.80)$ & & & & & & \\
\hline \multicolumn{13}{|c|}{ Ria de Aveiro } \\
\hline 0 & 1 & 9.661 & 155.368 & 4.790 & 4.930 & & 0.0001 & 0.0004 & 0.0156 & 0.0117 & & 0.622 \\
\hline 0 & 2 & 9.760 & 81.137 & 4.818 & 4.932 & 1.281 & 0.0001 & 0.0108 & 0.0135 & 0.0106 & 0.0291 & 0.655 \\
\hline \multicolumn{13}{|c|}{ Mira Estuary } \\
\hline-1 & 1 & 256.013 & 2663.381 & & 122.738 & & 0.0001 & 0.0059 & & 0.0264 & & 0.369 \\
\hline-2 & 1 & 263.967 & 2870.178 & & 130.998 & & 0.0001 & 0.0028 & & 0.0168 & & 0.386 \\
\hline-1 & 2 & 299.110 & 1839.301 & & 126.955 & & 0.0001 & 0.0036 & & 0.0196 & & 0.430 \\
\hline-2 & 2 & 264.377 & 1450.748 & & 134.338 & & 0.0004 & 0.0261 & & 0.0194 & & 0.386 \\
\hline 0 & 3 & 292.924 & 1184.013 & & 120.566 & & 0.0002 & 0.0158 & & 0.0274 & & 0.376 \\
\hline-1 & 3 & 301.172 & 1250.050 & & 131.658 & & 0.0002 & 0.0116 & & 0.0178 & & 0.418 \\
\hline 0 & 4 & 304.492 & 959.110 & & 125.442 & & 0.0003 & 0.0187 & & 0.0220 & & 0.380 \\
\hline
\end{tabular}




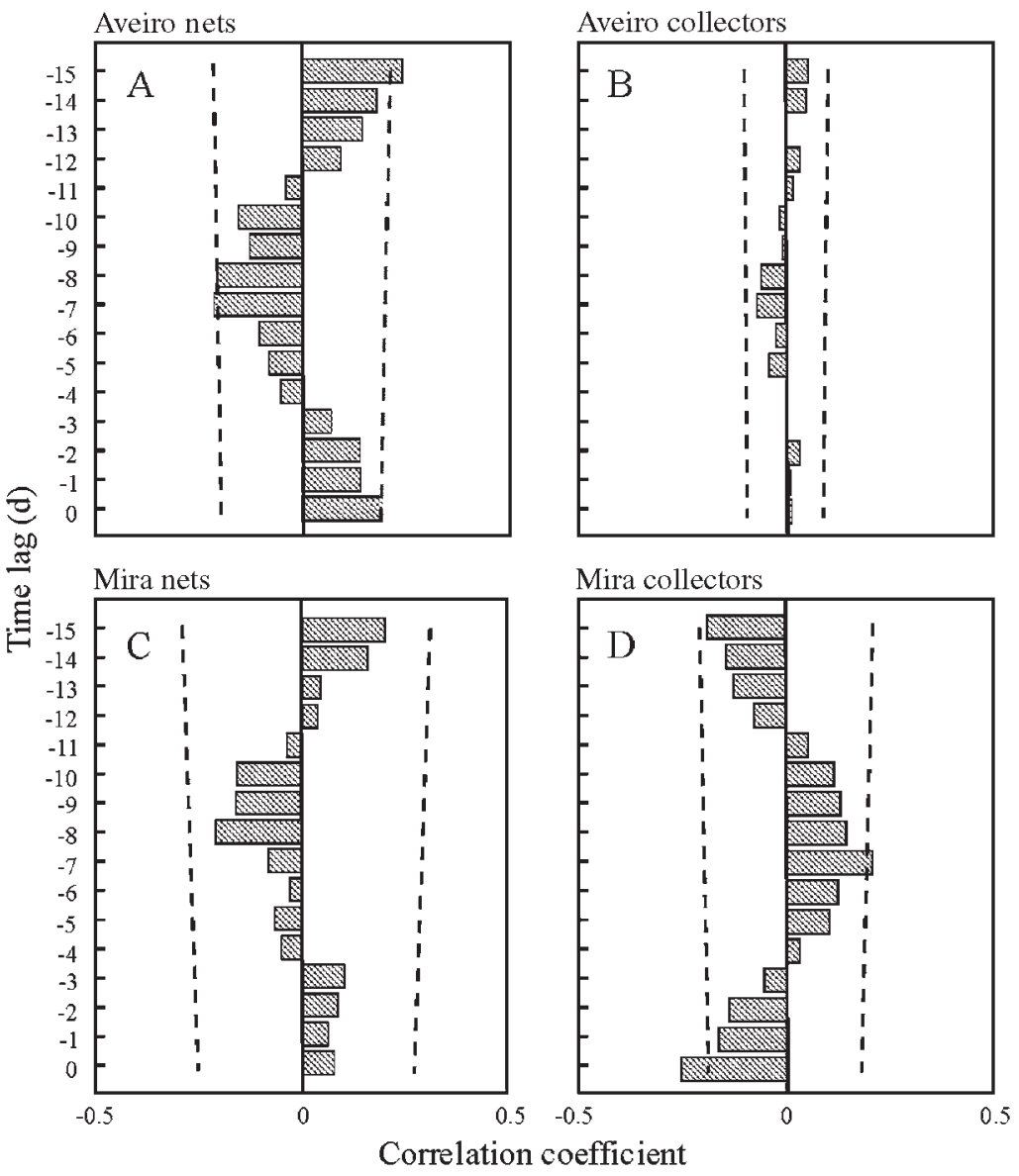

Fig. 7. Carcinus maenas. Cross-correlograms between tidal range and number of megalopae collected by passive nets at (A) Ria de Aveiro and (C) Mira Estuary, and between tidal range and number of megalopae from collectors deployed at (B) mixed site at Ria de Aveiro and (D) Mira Estuary. Dashed line: approximate $95 \%$ CI

measured by the $r^{* 2}$ statistic, were better at the Ria de Aveiro than at the Mira Estuary. At the Ria de Aveiro a significant effect of the wind was detected only for lags of $0 \mathrm{~d}$, while for the Mira Estuary significance of the wind was obtained with lags of 0 to $-2 \mathrm{~d}$. At both estuaries the highest fits were obtained for the cumulative wind stress series calculated over time windows of $2 \mathrm{~d}$, indicating a possible influence of wind events spreading over $2 \mathrm{~d}$. In all cases the wind stress coefficients were positive, i.e. southerly winds resulted in increased supply of megalopae to the estuaries.

Cross-correlation analysis between larval supply at the Ria de Aveiro and the Mira Estuary did not give significant results at any lag (data not shown). Settlement in the collectors showed strong peaks during neap tides around quarter moons at the Mira Estuary, but clear patterns related to the semilunar cycle were not detected at the Ria de Aveiro (Figs. 5B,C \& 6B,C). Crosscorrelations analyses between tidal range and captures in the collectors for the mixed site (Fig. 7B,D), for which longer times series were available at both locations, showed a pattern for the Mira Estuary, with negative values at lags around 0 and $-15 d_{i}$ this contrasts with the pattern obtained for the plankton nets (Fig. 7C). There was no periodic pattern on collectors at the Ria de Aveiro. These results indicate that settlement was decoupled from supply within estuaries.

Daily captures of Carcinus maenas megalopae by the collectors (Figs. 5B,C \& 6B,C, Table 3$)$ at the mixed sites were significantly higher than at the Zostera noltii sites (Ria de Aveiro $t=4.221, \mathrm{n}=115, \mathrm{p}<$ 0.001; Mira Estuary $t=3.259, \mathrm{n}=62, \mathrm{p}<$ 0.01 ). Correlation between settlement in the mixed and in the $Z$. noltii sites was highly significant at the Mira Estuary $(\mathrm{r}=$ $0.44, \mathrm{n}=64, \mathrm{p}<0.001$ ) and close to statistical significance at the Ria de Aveiro $(\mathrm{r}=$ $0.17, \mathrm{n}=114, \mathrm{p}<0.07$ ) at a lag of $0 \mathrm{~d}$. Therefore, settlement appears to be synchronised across sites within estuaries.

\section{DISCUSSION}

It is often difficult to identify causal relationships in the natural environment (Shrader-Frechette \& McCoy 1993). In the present study such a problem results from the attempt to describe processes that occur on the shelf from observations made inside the estuaries; ideally, inferences on the mechanisms for cross-shelf transport of larvae should be based on observations made on the shelf, in order to avoid the confounding effect of changes in behavior and physical processes taking place as the larvae enter the estuaries (Shanks 1998). We attempted to minimize this problem by setting our sampling stations within 1 tidal excursion from the inlets of the estuaries, to reduce the possible effects of accumulation of larvae between the inlet and the sampling stations, and to maximize the link between larval abundance inside the estuaries and in the nearshore waters. A second shortcoming created by the lack of observations on larval abundance on the shelf is that a decrease in supply level need not mean that the appropriate physical setting for transport is not occurring, but rather that there are no larvae to be transported. Therefore, the predictive power of our models decreases and this could obscure the role of other variables. Nevertheless, the results reported in the present study support the 2 main hypotheses under test, i.e. that supply of megalopae to estuaries on the Portuguese west coast 
occurs with a semilunar periodicity and that supply levels are higher during relaxation of equatorward (upwelling-favorable) winds. Differences were found between the northern and southern locations regarding the response of the coastal ocean to wind forcing, overall supply levels, vertical distribution of megalopae in the water column, and site-specific settlement.

\section{Wind-driven supply}

Northwesterly winds dominated the study period, in agreement with the expected scenario. Maximum positive and significant correlation values of SSL, SST and SST anomaly with wind stress were observed at time lags of 0 and $-1 \mathrm{~d}$ at the Ria de Aveiro (north coast), indicating a quick response of the coastal ocean to changes in the intensity of the alongshore wind. In the Mira Estuary (southern coast) variations of SSL and SST anomaly were uncorrelated with wind stress, while SST was strongly correlated at a time lag of $-5 \mathrm{~d}$. The nature of the wind regime also differed between the 2 geographic locations, with 2 dominant periods of oscillation of 3 and $6 \mathrm{~d}$ in the north, and 4 less defined periodic components varying from 2 to $9 \mathrm{~d}$ in the south.

A positive effect of wind stress on supply of Carcinus maenas megalopae was detected at both locations, supporting the hypothesis that onshore convergence of the surface layer during these periods transports the larvae shoreward. However, slight differences between the northern and southern locations concerning the response of supply were observed. At the Ria de Aveiro the effect of the wind was significant only at a lag of $0 \mathrm{~d}$, indicating a quick response of the transport mechanism that matched the delay between wind stress and changes in sea level and surface temperature. At the Mira Estuary a slower response was detected, reflected in time lags of 0 to $-2 \mathrm{~d}$ for the most significant effect of wind stress on supply. These results suggest that the differences in the patterns of supply of megalopae between the northern and the southern locations are due to differences in the response of the coastal ocean to wind stress patterns in terms of the cross-shore components of circulation.

The influence of wind circulation on larval supply also depends on the vertical distribution of the larvae. Relaxation or reversal of upwelling-favorable winds will result in coastward advection of larvae provided they are retained in the upwelling front (Roughgarden et al. 1991) or remain in the surface Ekman layer, but offshore transport will occur if the larvae occupy the bottom Ekman layer (Blanton et al. 1995). Using a modeling approach, Marta-Almeida (2006, this volume) showed that nocturnal diel vertical migration of larvae spanning several 10s of meters, a widespread behaviour in decapod larvae (Queiroga \& Blanton 2004), may enhance retention of larvae close to the coast under upwelling conditions. The interpretation of the sign of the association and of the lags between wind events and supply depends on the position occupied by the larvae in the water column, as well as on the distance larvae lie from the coast and the rates of advection during downwelling. Rates of coastward advection of 5 to $10 \mathrm{~km} \mathrm{~d}^{-1}$ have been estimated for the Portuguese coast following relaxation of northerly winds (Fiúza 1984). If the larvae are concentrated in the inner shelf as a result of vertical migration behaviour, a very short delay could result, explaining the time lags of 0 to $-2 \mathrm{~d}$ obtained in the present study.

The relationship between upwelling circulation and larval supply may be more complex and involve more than cross-shore transport, because of strong alongshore currents that may distribute the larvae regionally and interact with coastal topography (Wing et al. 1995). It is possible that inter-regional differencesand, for that matter, also intra-regional patternsdetected in the present study may be explained by variation of the alongshore circulation and by larval availability.

\section{Tide-driven supply}

A 2 wk period of oscillation of supply of Carcinus maenas megalopae was found, with higher supply around spring tides. Other semilunar patterns of supply to estuarine populations have been detected in only 2 other crab species (Callinectes sapidus, van Montfrans et al. 1995; Cancer magister, Miller \& Shanks 2004). Other cases of estuarine crabs where a similar pattern of megalopal supply was detected concern species assemblages from tropical or subtropical mangrove systems (Moser \& Macintosh 2001, Paula et al. 2001) where resolution to species level was not possible due to unavailability of larval descriptions. Crosscorrelograms indicated a delay of $0 \mathrm{~d}$ between tidal range and supply of $C$. maenas megalopae in the present study. This is similar to the studies of Moser \& Macintosh (2001) and Paula et al. (2001), but differs from the delays detected by Miller \& Shanks (2004). Miller \& Shanks (2004) found that maximum abundance of C. magister megalopae occurred 4 to $5 \mathrm{~d}$ after maximum amplitude of the tide, and they attributed this effect to a combination of onshore transport by internal waves and diel vertical migration on a background of tidal currents.

The immediate response of supply of Carcinus maenas megalopae to the amplitude of the tide in the present study is consistent with the immediate responses of megalopae to hydrostatic pressure, salinity and tur- 
bulence during selective tidal stream transport, which increase with increasing tidal range in megalopae of estuarine species (De Vries et al. 1994, Tankersley et al. 1995 Welch \& Forward 2001). These reactions can only be triggered if the megalopae are already in nearshore waters or inside the estuary, resulting in an immediate change in larval concentration in the lower estuary. It has been argued that, since supply of crab megalopae into estuaries tends to occur during night flood tides, the number of flood hours during darkness could influence the level of supply (Christy \& Morgan 1998), resulting in a different phasing of supply relative to the spring/neap cycle. In the present case, since co-occurrence of darkness and flood currents is optimised at spring tides during the part of the year when the study took place (Queiroga \& Blanton 2004), such an effect may be responsible for the intensification of supply peaks, but not for their displacement relative to the tide amplitude cycle.

On the basis of the observed lags between tidal range and supply, the hypotheses that internal tidal bore and internal wave mechanisms are implicated in the onshore transport of megalopae cannot be entirely rejected, although they appear to be less strongly supported. If internal tidal bore transport should occur, it would operate also on megalopae that are close to the shore, again resulting in an immediate supply. In a study conducted on the west coast of the USA, Pineda (1995) showed that internal tidal bores recur with a 2 wk periodicity, but that they do not tend to coincide with spring tides. The mechanism explaining this phase relationship is that, although the formation of internal waves is more probable during spring tides because of stronger currents, large amplitude tides tend to disrupt the thermocline, so that internal waves break far from the shore. In order for internal tidal bores to be implicated in the supply of Carcinus maenas megalopae to estuaries on the Portuguese coast, internal bores would have to coincide with maximum amplitude tides. A similar argument applies to the internal wave hypothesis. Additionally, assuming that the internal tidal wave mechanism is effective in transporting megalopae across the shelf, $C$. maenas megalopae are mostly not neustonic (Zeng \& Naylor 1996b), which would result in a reduced rate of transport. A very particular timing of the occurrence of internal waves along the semilunar cycle would have to be assumed to account for the observed time lags.

\section{Supply levels}

Much higher levels of supply and settlement were detected at the Mira Estuary than at the Ria de Aveiro. This may be related to the distribution of large Carci- nus maenas populations along the coast of Iberia, and to a general southward flow during the larval season. In the north, the Ria de Aveiro is the only estuarine system with the potential to harbour a large population of the species, whereas on the south coast the Tagus and Sado estuaries may contribute large numbers of larvae to shelf waters, and these larvae could be carried southward by the prevailing circulation during spring and summer. Supply was not correlated across regions at any lag. Since supply seems to be controlled by tidal range, which is synchronised along the Portuguese coast, the lack of correlation may be due to interregional differences in overall level of larval abundance, particularly if they are related to zones of retention over the shelf.

Abundances in the surface and bottom plankton nets were similar at the Ria de Aveiro, but more larvae were collected at the surface in the Mira Estuary. These differences may be related to higher turbulence levels that would force megalopae to swim more in the water column at the Mira Estuary (Welch et al. 1999). Interestingly, settlement was more intense at this estuary during neap tides, which may also be attributed to an effect of turbulence (see below).

\section{Settlement}

Settlement of Carcinus maenas megalopae on the collectors was synchronised across habitats within each estuary, but was higher at the mixed than at the Zostera noltii sites. J. Paula et al. (unpubl. data) conducted a comparison of settlement on collectors against megalopal density on the sediment at the Mira Estuary, for vegetated and unvegetated substrates. The study showed that density of megalopae on the substrate was higher in $Z$. noltii habitats than at unvegetated sites, but that captures on the collectors were higher at the unvegetated sites. The pattern was interpreted as a search for the physical protection provided by the collectors at the unvegetated sites, where refuges are less common, whereas the natural structural complexity of the $Z$. noltii habitat would provide such refuges. Therefore, the higher settlement on the collectors at the mixed site observed in the present study may be an artifact of the sampling method influenced by differences in habitat complexity among sites.

Similarly to supply, settlement on the collectors was not correlated across geographic locations. Desynchronised settlement across locations would be a logical result of desynchronised supply. However, maximum settlement occurred around neap tides at the Mira Estuary, therefore being clearly decoupled from supply, which is highest around spring tides, while settlement was uncorrelated with supply at the Ria de 
Aveiro (although the correlogram of Fig. $7 \mathrm{C}$ shows an indication of a weak synchronised rhythm). Several different causes could explain the observed pattern. One possible explanation assumes the influence of turbulence levels (Welch 1991), which may differ between estuaries or sites. Higher turbulence levels in the Mira Estuary, which are consistent with current velocities that are 10 to $40 \%$ higher at the Mira Estuary for tides of the same amplitude (Paula 1993, Queiroga 1995), could prevent the megalopae from settling during spring tides. The competence state of the megalopae may also delay settlement. Competence is defined as the ability of larval forms to respond to settlement stimuli (Crisp 1974). In crab megalopae competence depends on the physiological stage of the larvae (Forward et al. 2001). Several studies indicate a progression of the intermoult stage of crab megalopae as they approach settlement habitats (Metcalf \& Lipcius 1992, Morgan et al. 1996, Zeng et al. 1997, Moksnes \& Wennhagen 2001), and differences in intermoult stage can sometimes be found within estuaries (Lipcius et al. 1990). It is possible that the delay between supply and settlement in the Mira Estuary could be due to supply from a pool of megalopae in an earlier stage of development (Hasek \& Rabalais 2001). Density-dependent secondary dispersal, such as that detected in juveniles of several benthic invertebrates (e.g. Turner et al. 1997, Reyns et al. 2004) is another possible factor. During spring tides at the Mira Estuary, a large number of settling megalopae may be offset by those leaving after settlement, because of crowding. In either case, this highlights that supply of larvae to estuarine systems may be decoupled from settlement, because of estuarine, site-specific, or larval characteristics.

The results obtained in the present study demonstrate a cyclic pattern of supply of Carcinus maenas megalopae to estuaries on the west coast of Portugal, related to the tide amplitude. The $0 \mathrm{~d}$ time lag observed between tide amplitude and supply suggests that selective tidal stream transport is the main process responsible for the supply of the larvae to the estuaries, although the internal wave and internal tidal bore mechanisms cannot be entirely rejected based on the observations. Selective tidal stream transport can only operate on larvae that have already been transported to nearshore waters by some other process. Supply to nearshore waters appears to be at least partly controlled by the dynamics of wind-driven circulation. The sampling methods that were used may be relevant for other studies of the effects of physical forcing on supply and settlement of estuarine invertebrates, because a combination of passive plankton nets and settlement bottom-deployed collectors enable the independent assessment of supply and settlement.
Acknowledgements. The authors are indebted to Mr. I. Gomes da Silva for his help with fieldwork in the Mira estuary, and to A. Dinis, S. Vieira and S. Oliveira for field and laboratory support. Fundação para a Ciência e a Tecnologia (FCT) supported Post-Doc grants to A.A.V.F. (No. SFRH/ BPD/7189/2001) and I.G.-G. (SFRH/BPD/1596/2000), as well as a PhD grant to M.J.A. (SFRH/BD/6843/2001). The PRODEP program funded research grants to I.S. and to S.F. This work is part of the 'ProRecruit-Shelf processes controlling recruitment to littoral populations in an eastern oceanic boundary: using barnacles and crabs as models' research project, also funded by FCT (No. POCTI/1999/BSE/ 36663). Financial support was allocated by FCT under the Support Community Framework III, Operational Programme Science, Technology and Innovation. This study is a Portuguese contribution to GLOBEC.

\section{LITERATURE CITED}

Almeida MJ, Queiroga H (2003) Physical forcing of onshore transport of crab megalopae in the northern Portuguese upwelling system. Estuar Coast Shelf Sci 57:1091-1102

Alpuim T, El-Shaarawi A (in press) On the efficiency of regression analysis with $\mathrm{AR}(\mathrm{p})$ errors. J Appl Stat

Andrade FA, Reis M, Duarte P (1991) The dynamics of the tide excursion in the Mira estuary (Vila Nova de Milfontes, Portugal). A Lagrangian approach. In: Elliott M, Ducrotoy JP (eds) Estuaries and coasts: spatial and temporal intercomparisons. Olsen \& Olsen, Fredensborg, p 49-55

Bakun A (1996) Patterns in the ocean: ocean processes and marine population dynamics. California Sea Grant College System, La Jolla, CA

Barrosa JO (1985) Breve caracterização da Ria de Aveiro. Actas das Jornadas da Ria de Aveiro. Vol. II. Recursos da Ria de Aveiro. Câmara Municipal de Aveiro, Aveiro, p 9-14

Batschelet E (1979) Introduction to mathematics for life scientists. Springer-Verlag, Berlin

Blanton JO, Wenner EL, Werner F, Knott D (1995) Effects of wind-generated coastal currents on the transport of blue crab megalopae on a shallow continental shelf. Bull Mar Sci 57:739-752

Blanton JO, Andrade FA, Ferreira MA (2000) Effect of a broad sill on tidal circulation and salt transport in the entrance to a coastal plain estuary (Mira - Vila Nova de Milfontes, Portugal). Estuaries 23:293-304

Boehlert GW, Mundy BC (1988). Roles of behavioural and physical factors in larval and juvenile fish recruitment to estuarine nursery areas. Am Fish Soc Symp 3:51-67

Borges MF, Santos AMP, Crato N, Mota B (2003) Sardine regime shifts off Portugal: a time series analysis of catches and wind conditions. Sci Mar 67:235-244

Brockwell PJ, Davis RA (2002) Time series: theory and methods, 2nd edn. Springer, New York

Chatfield C (1996) The analysis of time series data: an introduction, 5th edn. Chapman \& Hall, London

Christy JH, Morgan SG (1998) Estuarine immigration by crab postlarvae: mechanisms, reliability and adaptive significance. Mar Ecol Prog Ser 174:51-65

Connolly SR, Menge BA, Roughgarden J (2001) A latitudinal gradient in recruitment of intertidal invertebrates in the northeast Pacific ocean. Ecology 82:1799-1813

Crisp DJ (1974) Factors influencing the settlement of marine invertebrate larvae. In: Grant PT, Mackie AM (eds) Chemoreception in marine organisms. Academic Press, London, p 177-265 
Dawirs RR (1985) Temperature and larval development of Carcinus maenas (Decapoda) in the laboratory: prediction of larval dynamics in the sea. Mar Ecol Prog Ser 24:297-302

deBruyn MH, Meuwig JJ (2001) Detecting lunar cycles in marine ecology: periodic regression versus categorical ANOVA. Mar Ecol Prog Ser 214:307-310

DeVries MC, Tankersley RA, Forward RB Jr, Kirby-Smith WW, Luettich RA Jr (1994) Abundance of estuarine crab larvae is associated with tidal hydrologic variables. Mar Biol 118:403-413

Dias JM (2001) Contribution to the study of the Ria de Aveiro hydrodynamics. PhD dissertation, Universidade de Aveiro

Duchêne JC, Queiroga H (2001) Use of an intelligent CCD camera for the study of endogenous vertical migration rhythms in first zoeae of the crab Carcinus maenas. Mar Biol 139:901-909

d'Udekem d'Acoz C (1999) Inventaire et distribution des crustacés décapodes de l'Atlantique nord-oriental, de la Méditerranée et des eaux continentales adjacentes au nord de $25^{\circ} \mathrm{N}$. Collection Patrimoine Naturel 40, Muséum National d'Histoire Naturelle, Paris

Epifanio CE, Garvine WW (2001). Larval transport on the Atlantic continental shelf of North America: a review. Estuar Coast Shelf Sci 52:51-77

Fiúza AFG (1984) Hidrologia e dinâmica das águas costeiras de Portugal. PhD dissertation, University of Lisbon

Fiúza AFG, Macedo ME, Guerreiro MR (1982) Climatological space and time variation of the Portuguese coastal upwelling. Oceanol Acta 5:31-40

Forward RB Jr, Rittschof D (1994) Photoresponses of crab megalopae in offshore and estuarine waters: implications for transport. J Exp Mar Biol Ecol 182:183-192

Forward RB Jr, Tankersley RA (2001) Selective tidal-stream transport of marine animals. Oceanogr Mar Biol Annu Rev 39:305-353

Forward RB Jr, Swanson J, Tankersley RA, Welch JM (1997) Endogenous swimming rhythms of blue crab, Callinectes sapidus, megalopae: effects of offshore and estuarine cues. Mar Biol 127:621-628

Forward RB Jr, Tankersley RA, Rittschof D (2001) Cues for metamorphosis of brachyuran crabs: an overview. Am Zool 41:1108-1122

Franks P (1997) Spatial patterns in dense algal blooms. Limnol Oceanogr 42:1297-1305

Frouin R, Fiúza AFG, Ambar I, Boyd TJ (1990) Observation of a poleward surface current off the coast of Portugal and Spain during winter. J Geophys Res 95:679-691

Fuller W (1976) Introduction to statistical time series. John Wiley \& Sons, New York

Gomes V (1991) O caranguejo Carcinus maenas (L.) da Ria de Aveiro: dados sobre o valor económico, avaliação do stock e esforção de pesca. In: Seminário Eurocoast-a zona costeira e os problemas ambientais. Câmara Municipal de Aveiro, Aveiro, p 159-166

Goodrich DM, van Montfrans J, Orth RJ (1989) Blue crab megalopal influx to Chesapeake Bay: evidence for a winddriven mechanism. Estuar Coast Shelf Sci 29:247-260

Grosholz ED, Ruiz GM (1995) Spread and potential impact of the recently introduced European green crab, Carcinus maenas, in central California. Mar Biol 122:239-247

Hasek B, Rabalais N (2001) A comparison of molt stages of blue crab megalopae, Callinectes sapidus (Rathbun), sampled with artificial collectors and plankton nets. J Exp Mar Biol Ecol 265:15-27

Hawkins SJ, Hartnoll RG (1982) Settlement patterns of Semibalanus balanoides (L.) in the Isle of Man (1977-1981). J Exp Mar Biol Ecol 62:271-283
Haynes R, Barton ED (1990) A poleward flow along the Atlantic coast of the Iberian Peninsula. J Geophys Res 95:11425-11441

Haynes R, Barton DE, Pilling I (1993) Development, persistence, and variability of upwelling filaments off the Atlantic coast of the Iberian peninsula. J Geophys Res 98:22681-22692

Helfrich KR, Pineda J (2003) Accumulation of particles in propagating fronts. Limnol Oceanogr 48:1509-1520

Huthnance JM, Aken HMV, White M, Barton ED and 5 others (2002) Ocean margin exchange-water flux estimates. J Mar Syst 32:107-137

Jorge da Silva A (1992) Dependence of upwelling related circulation on wind forcing and stratification over the Portuguese northern shelf. ICES CM 1992/C:17

Lipcius RN, Olmi EJ III, van Montfrans J (1990) Planktonic availability, molt stage and settlement of blue crab postlarvae. Mar Ecol Prog Ser 58:235-242

Little KT, Epifanio CE (1991) Mechanism for the reinvasion of an estuary by 2 species of brachyuran megalopae. Mar Ecol Prog Ser 68:235-242

Marques JC, Costa I (1983) Crustáceos decápodes do estuário do Tejo: distribuição das espécies e estudo da biologia das populaçães de Carcinus maenas (Decapoda, Brachyura), Crangon crangon, Palaemon longirostris, e Palaemon serratus (Decapoda, Caridea). Estudo Ambiental do Estuário do Tejo, CNA/Tejo no. 26, Rel. 23. Ministério da Qualidade de Vida, Gabinete de Estudos e Planeamento, Lisbon

Marta-Almeida M, Dubert J, Peliz Á, Queiroga H (2006) Influence of vertical migration pattern on retention of crab larvae in a seasonal upwelling system. Mar Ecol Prog Ser 307:1-19 (this volume)

Metcalf KS, Lipcius RN (1992) Relationship of habitat and spatial scale with physiological state and settlement of blue crab postlarvae in Chesapeake Bay. Mar Ecol Prog Ser 82:143-150

Metcalf KS, van Montfrans J, Lipcius RN, Orth RJ (1995) Settlement indices for blue crab megalopae in the York River, Virginia: temporal relationships and statistical efficiency. Bull Mar Sci 57:781-792

Miller JA, Shanks AL (2004) Ocean-estuary coupling in the Oregon upwelling region: abundance and transport of juvenile fish and of crab megalopae. Mar Ecol Prog Ser 271:267-279

Moksnes PO, Wennhage H (2001) Methods for estimating decapod larval supply and settlement: importance of larval behaviour and development stage. Mar Ecol Prog Ser 209:257-273

Morgan SG, Zimmer-Faust RK, Heck KL Jr, Coen LD (1996) Population regulation of blue crabs Callinectes sapidus in the northern Gulf of Mexico: postlarval supply. Mar Ecol Prog Ser 133:73-88

Moser SM, Macintosh DJ (2001) Diurnal and lunar patterns of larval recruitment of brachyura into a mangrove estuary system in Ranong Province, Thailand. Mar Biol 138: $827-841$

Nagaraj M (1993) Combined effects of temperature and salinity on the zoel development of the green crab, Carcinus maenas (Linnaeus, 1758) (Decapoda: Portunidae). Sci Mar $57: 1-8$

Paula J (1993) Ecologia das fases larvares e recrutamento de crustáceos decápodes no estuário do Rio Mira. PhD dissertation, University of Lisbon

Paula J, Dray T, Queiroga H (2001) Interaction of offshore and inshore processes controling settlement of brachyuran megalopae in Saco mangrove creek, Inhaca Island (South Mozambique). Mar Ecol Prog Ser 215:251-260 
Pineda J (1991) Predictable upwelling and the shoreward transport of planktonic larvae by internal tidal bores. Science 253:548-551

Pineda J (1994) Internal tidal bores in the nearshore: warmwater fronts, seaward gravity currents and the on-shore transport of neustonic larvae. J Mar Res 52:427-458

Pineda J (1995) An internal tidal bore regime at nearshore stations along western USA - predictable upwelling within the lunar cycle. Cont Shelf Res 125:1023-1041

Pineda J (1999) Circulation and larval distribution in internal tidal bore warm fronts. Limnol Oceanogr 44:1400-1414

Pritchard DW (1967) What is an estuary: physical viewpoint. In: Lauff GE (ed) Estuaries. American Association for the Advancement of Science, Washington, p 3-5

Queiroga H (1995) Processos de dispersão e recrutamento das larvas do caranguejo Carcinus maenas (L.) na Ria de Aveiro. PhD dissertation, Universidade de Aveiro

Queiroga H (1996) Distribution and drift of the crab Carcinus maenas (L.) (Decapoda, Portunidae) larvae over the continental shelf off northern Portugal in April 1991. J Plankton Res 18:1981-2000

Queiroga H (1998) Vertical migration and selective tidal stream transport in the megalopa of the crab Carcinus maenas. Hydrobiologia 375/376:137-149

Queiroga H (2003) Wind forcing of crab megalopae recruitment to an estuary (Ria de Aveiro) in the northern Portuguese upwelling system. Invertebr Reprod Dev 43: $47-54$

Queiroga H, Blanton JO (2004) Interactions between behaviour and physical forcing in the control of horizontal transport of decapod crustacean larvae: an overview. Adv Mar Biol 47:107-214

Queiroga H, Costlow JD Jr, Moreira MH (1994) Larval abundance patterns of Carcinus maenas (Decapoda, Brachyura) in Canal de Mira (Ria de Aveiro, Portugal). Mar Ecol Prog Ser 111:63-72

Queiroga H, Costlow JD Jr, Moreira MH (1997) Vertical migration of the crab Carcinus maenas first zoea in an estuary: implications for tidal stream transport. Mar Ecol Prog Ser 149:121-132

Quinn GP, Keough MJ (2002) Experimental design and data analysis for biologists. Cambridge University Press, Cambridge

Reyns NB, Eggleston DB (2004) Environmentally-controlled, density-dependent secondary dispersal in a local estuarine crab population. Oecologia 140:280-288

Roughgarden J, Pennington JT, Stoner D, Alexander S, Miller K (1991) Collisions of upwelling fronts with the intertidal zone: the cause of recruitment pulses in barnacle populations of central California. Acta Oecol 12:3551

Shanks AL (1983) Surface slicks associated with tidally forced internal waves may transport pelagic larvae of benthic invertebrates and fishes shoreward. Mar Ecol Prog Ser 13:311-315

Shanks AL (1985) Behavioral basis of internal-wave-induced shoreward transport of megalopae of the crab Pachygrapsus crassipes. Mar Ecol Prog Ser 24:289-295

Shanks AL (1988) Further support for the hypothesis that internal waves can cause shoreward transport of larval invertebrates and fishes. Fish Bull 86:703-714

Shanks AL (1995) Mechanisms of cross-shelf dispersal of larval invertebrates and fish. In: McEdward L (ed) Ecology of marine invertebrate larvae. CRC Press, Boca Raton, FL, p 323-367

Shrader-Frechette KS, McCoy ED (1993) Method in ecology: strategies for conservation. Cambridge University Press, New York

Editorial responsibility: Otto Kinne (Editor-in-Chief), Oldendorf/Luhe, Germany
Sokal RR, Rohlf FJ (1995) Biometry, 3rd edn. Freeman, New York

Sponaugle S, Lee T, Koufaralou V, Pinkard D (2005) Florida current frontal eddies and the settlement of coral reef fishes. Limnol Oceanogr 50:1033-1048

Sprung M (1994) High larval abundances in the Ria Formosa (Southern Portugal)-methodological or local effect? J Plankton Res 16:151-160

Tankersley RA, McKelvey LM, Forward RB Jr (1995) Responses of estuarine crab megalopae to pressure, salinity and light: implications for flood-tide transport. Mar Biol 122:391-400

Tapia FJ, Pineda J, Ocampo-Torres FJ, Fuchs HL, Parnell PE, Montero P, Ramos S (2004) High-frequency observations of wind-forced onshore transport at a coastal site in Baja California. Cont Shelf Res 24:1573-1585

Thresher R, Proctor C, Ruiz G, Gurney R, MacKinnon C, Walton W, Rodriguez L, Bax N (2003) Invasion dynamics of the European shore crab, Carcinus maenas, in Australia. Mar Biol 142:867-876

Turner SJ, Grant J, Pridmore RD, Hewitt JE, Wilkinson MR, Hume TM, Morrisey DJ (1997) Bedload and water-column transport and colonization processes by post-settlement benthic macrofauna: does infaunal density matter? J Exp Mar Biol Ecol 216:51-75

van Montfrans J, Epifanio CE, Knott DM, Lipcius RN and 7 others (1995) Settlement of blue crab postlarvae in western North Atlantic estuaries. Bull Mar Sci 57:834-854

Vicente CM (1985) Caracterização hidráulica e aluvionar da Ria de Aveiro. Utilização de modelos hidráulicos no estudo de problemas da Ria. Actas das Jornadas da Ria de Aveiro. Vol. III. Ordenamento da Ria de Aveiro. Câmara Municipal de Aveiro, Aveiro, p 41-58

Wei WS (1990) Time series analysis: univariate and multivariate methods. Addison Wesley, Reading, MA

Welch JM, Forward RB Jr (2001) Flood tide transport of blue crab, Callinectes sapidus, postlarvae: behavioral responses to salinity and turbulence. Mar Biol 139:911-918

Welch JM, Forward RB Jr, Howd PA (1999) Behavioral responses of blue crab Callinectes sapidus larvae to turbulence: implications for selective tidal stream transport. Mar Ecol Prog Ser 179:135-143

Wing SR, Largier JL, Botsford LW, Quinn JF (1995) Settlement and transport of benthic invertebrates in an intermittent upwelling region. Limnol Oceanogr 40:316-329

Wooster WS, Bakun A, McLain DR (1976) The seasonal upwelling cycle along the eastern boundary of the North Atlantic. J Mar Res 34:131-141

Zeldis JR, Jillett JB (1982) Aggregation of pelagic Munida gregaria (Fabricius) (Decapoda, Anomura) by coastal fronts and internal waves. J Plankton Res 4:839-857

Zeng C, Naylor E (1996a). Endogenous tidal rhythms of vertical migration in field collected zoea-1 larvae of the shore crab Carcinus maenas: implications for ebb tide offshore dispersal. Mar Ecol Prog Ser 132:71-82

Zeng C, Naylor E (1996b) Occurrence in coastal waters and endogenous tidal swimming rhythms of late megalopae of the shore crab Carcinus maenas: implications for onshore recruitment. Mar Ecol Prog Ser 136:69-79

Zeng C, Naylor E (1996c) Synchronization of endogenous tidal vertical migration rhythms in laboratory-hatched larvae of the crab Carcinus maenas. J Exp Mar Biol Ecol 198:269-289

Zeng C, Abelló P, Naylor E (1997) Endogenous tidal and semilunar moulting rhythms in early juvenile shore crabs Carcinus maenas: adaptations to a high intertidal habitat. Mar Biol 128:299-305

Submitted: September 20, 2005; Accepted: December 12, 2005 Proofs received from author(s): January 6, 2006 